\title{
Environmental and Production Cost Impacts of No-Till: Estimates from Observed Behavior
}

MARITA LAUKKANEN AND CÉLINE NAUGES 
Environmental and production cost impacts of no-till: estimates from observed behavior

\author{
Marita Laukkanen \\ MTT Agrifood Research Finland \\ Luutnantintie 13 \\ 00410 Helsinki \\ Finland
}

Céline Nauges

Toulouse School of Economics (LERNA-INRA)

Manufacture des Tabacs

21 Allée de Brienne

31000 Toulouse, France

This draft, 11 December 2009

Céline Nauges is a senior researcher at the French Institute for Research in Agriculture (INRA) and Toulouse School of Economics. Marita Laukkanen is a senior researcher at MTT Agrifood Research Finland. 
Environmental and production cost impacts of no-till: estimates from observed behavior

\begin{abstract}
No-till has been promoted as a cultivation method that reduces both production costs and the environmental impacts of farming relative to conventional tillage. Using farmlevel data from Finland, we show that no-till has no statistically significant effect on total variable costs but that it increases the use of plant protection products and fertilizers, and decreases the use of labor. An environmental impact simulation combining the results on input use with a nutrient and herbicide runoff model predicts that no-till produces environmental benefits on highly erodible land, but may be even detrimental to the environment in average conditions.
\end{abstract}




\section{Introduction}

No-till cultivation systems leave fields unturned and allow crop stubble to remain on the soil surface from harvest to sowing. The stubble protects the soil surface, and experimental studies have confirmed that no-till farming markedly reduces erosion, nitrogen runoff and particulate phosphorus runoff (see e.g. Soileau et al. 1994, Stonehouse 1997, Puustinen et al. 2005). Financial analyses of no-till have suggested that it also produces economic benefits to farms, in the form of an overall reduction in input costs (see e.g. Clark et al. 1994, Stonehouse 1997). These findings have prompted interest in no-till as a cultivation technology that would benefit both farmers and the environment. However, no-till has also been linked to undesirable environmental effects, in particular increased loading of dissolved reactive phosphorus (see e.g. Holland 2004, Puustinen et al. 2005) and leaching of herbicides due to increased herbicide application (see e.g. Holland 2004, Rose and Carter 2003).

From an environmental policy perspective, it is important to assess the overall environmental and economic impacts of no-till. Previous empirical research on the performance of no-till is largely limited to field experiments, with completely homogenous production conditions apart from the no-till treatment effect, and to econometric analyses studying the factors influencing the adoption of no-till and other conservation tillage practices (see e.g. Knowler and Bradshaw, 2007, for a review). There exists little empirical evidence on the economic impact of adoption on individual farmers. Kurkalova et al. (2006) provide an exception; they estimate the effect of no-till on farm profits and quantify the adoption premium associated with uncertainty based on observed behavior. The impact of no-till on herbicide use is another issue that has received little attention in an empirical context. Thus, there is little empirical information for evaluating the private and social benefits of no-till, while such information would be key both for evaluating the desirability of policies to encourage adoption, and for 
designing policies if deemed desirable. A recent study by Lankoski et al. (2006) provides a theoretical framework for analyzing the private and social profitability of no-till, and applies the model to short-term experimental data. Their findings indicate that the environmental benefits of no-till may not be sufficient to offset the costs pertaining primarily to yield losses. ${ }^{\mathrm{i}}$ To predict the consequences of no-till adoption on a larger scale, it is vital to also investigate the impacts of no-till when heterogeneous farm and regional characteristics are accounted for.

The gap in knowledge pertaining to the evaluation of overall environmental and economic impacts of no-till based on observed farm-level data provides the primary motivation for the present research. The paper focuses on empirical assessment of the impact of no-till on production costs, and labor, plant protection and fertilizer input use, in a way that accounts for farm-specific characteristics. We specify a two-stage model that determines the effect of notill on production costs and input demands, and the factors driving a farm's decision to adopt no-till technology. This approach, which builds on Khanna and Damon (1999), controls for sample selection bias and the effect of farm characteristics on the environmental and economic performance of no-till. We use a panel data set with close to 900 observations from Southern Finland, the main crop production region in the country. The research complements field experiments tied to homogenous producer characteristics. It also provides a large-scale point of comparison for the results obtained by Lankoski et al. (2006) on the societal impacts of no-till. Finally, it produces the first set of estimates of the factors influencing no-till adoption in Europe, where no-till is not nearly as widely used as in the Americas and Australia. ${ }^{\text {ii }}$

The rest of the paper is organized as follows. Section 2 describes the modeling framework and the empirical model. Section 3 discusses the data used in the study and the factors expected to 
influence no-till adoption. Section 4 discusses the estimation procedure, and presents the estimation results and an environmental simulation on the impacts of no-till on nutrient and herbicide runoffs.

\section{Modeling framework}

We assume that in each period a farmer who has previously cultivated grains using conventional tillage can decide to continue the conventional practice, or to adopt no-till as a new technology. We use owning no-till machinery as a proxy for no-till adoption, and proceed from the assumption that using no-till requires investment in new machinery. For simplicity, we assume that a farmer who invests in no-till machinery in year $\bar{t}$ will be using it from year $\bar{t}+1$ onwards. Based on the results of Koundouri et al. (2009), we assume that farmers are risk-neutral. ${ }^{\text {iii }}$ Farm $i$ then chooses no-till if its expected discounted net benefits from production using no-till are greater than the expected net benefits of production using conventional tillage. In each period farm $i$ also chooses input quantities that minimize the cost of producing grains, taking input prices and the tillage system as given.

We suppose that farm $i$ 's production cost in year $t, C_{i t}$, is determined by its grain output, $y_{i t}$, a vector of input prices, $\mathbf{w}_{i t}$, and a vector of farm-specific variables, $\mathbf{z}_{i t}$. In particular, the vector $\mathbf{z}_{i t}$ contains the variable $d_{i t}$ that describes farm $i$ 's technology choice, equal to 1 if the farm $i$ owns no-till machinery and 0 otherwise. The production cost has the following general form:

$$
C_{i t}=C\left(y_{i t}, \mathbf{w}_{i t}, \mathbf{z}_{i t}\right) \text {. }
$$

Among a farm's factors of production, the capital stock cannot in general be adjusted as easily as other inputs. We focus on farm $i$ 's production costs throughout the growing season and assume the capital stock to be fixed at a predetermined level. The cost function (1) should 
thus be interpreted as a short-run variable cost function. The optimal choices of the short-run variable factor levels will generally depend on the capital stock, which we include as a control variable in the $\mathbf{z}_{i t}$ vector (see e.g. Caves, Christensen, and Swanson, 1981, for a similar approach).

We specify the production cost as a Translog functional form (see Christensen, Jorgenson, and Lau, 1973), which is a flexible form in the sense that it provides a second-order approximation to any unknown cost function. The generalized Translog cost function for a representative farmer has the following form:

$$
\begin{aligned}
& \ln C_{t}=\beta_{0}+\beta_{y} \ln y_{t}+\sum_{j} \lambda_{j} \ln w_{j t}+\sum_{r} \gamma_{r} \ln z_{r t}+\frac{1}{2} \beta_{y y} \ln y_{t} \ln y_{t}+\frac{1}{2} \sum_{j} \sum_{m} \lambda_{j m} \ln w_{j t} \ln w_{m t} \\
& +\frac{1}{2} \sum_{r} \sum_{s} \gamma_{r s} \ln z_{r t} \ln z_{s t}+\sum_{j} \rho_{j} \ln y_{t} \ln w_{j t}+\sum_{r} \kappa_{r} \ln y_{t} \ln z_{r t}+\sum_{j} \sum_{r} \eta_{j r} \ln w_{j t} \ln z_{r t}+\mu_{i t},
\end{aligned}
$$

where $\lambda_{j m}=\lambda_{m j}$ and $\gamma_{r s}=\gamma_{s r}$. Term $C_{t}$ represents total variable costs in year $t, \beta_{0}$ is a constant, and $j$ indices variable inputs and $r$ farm-specific variables controlling for heterogeneity in the population of farmers. Theory requires that the cost function be homogeneous of degree one in input prices, which is typically satisfied by dividing the variable cost and the input prices by the price of one input. The homogeneity property implies the following restrictions on the parameters of the Translog cost function:

$$
\sum_{j} \lambda_{j}=1, \sum_{j} \lambda_{j m}=\sum_{m} \lambda_{m j}=\sum_{j} \eta_{j r}=\sum_{j} \rho_{j}=0
$$

The theory of cost and production also requires that the own-price elasticities of the variable inputs be negative and that the Hessian matrix, $\left[\partial^{2} C / \partial w_{j} \partial w_{m}\right]$, be negative semidefinite. We will verify that these properties are satisfied on our data at the estimation stage. 
Given the large number of parameters to be estimated in (2), efficiency of the estimates will be improved if the cost function is estimated simultaneously with the cost share equations implied by Shephard’s (1953) lemma:

$$
\frac{w_{j t} q_{j t}}{C_{t}}=S_{j t}=\frac{\partial \ln C_{t}}{\partial \ln w_{j t}}=\lambda_{j}+\sum_{m} \lambda_{j m} \ln w_{m t}+\rho_{j} \ln y_{t}+\sum_{r} \eta_{j r} \ln z_{r t}
$$

for $j=l, p, f$, where $q_{j t}$ represents derived demand of input $j$ in year $t$. The Translog cost function along with the input cost share equations will be estimated using Zellner's (1962) technique for the estimation of a system of seemingly unrelated equations.

In the cost model, the technology choice, $d_{i t}$, cannot be treated as exogenous, since the decision of a farm to adopt no-till is likely to be influenced by the same observable and unobservable farm characteristics that affect the cost of production. For example, a farmer with a high level of education may have more knowledge about new technologies and may thus be more likely to adopt no-till than a farmer with less education. It is also possible that a farmer with more education is more efficient and has a lower production cost than a farmer with less education, even when both use the same technology. To overcome possible selfselection bias when estimating the cost model, we apply a two-stage procedure, as Khanna and Damon (1999) have done, which involves modeling a farmer's decision to invest in a notill machine as an endogenous variable.

We assume that a farmer decides to invest in no-till machinery in period $t$ if the expected net benefit of this decision is positive in year $t$, as well as in all subsequent years. Farm $i$ 's expected net benefit from using no-till is $d_{i t}^{*}=\mathbf{X}_{i t}^{\prime} \boldsymbol{\theta}+\varepsilon_{i t}$, where the vector $\mathbf{X}_{i t}$ includes characteristics of the farm and its environment. The decision model at time $t$ is written as

$$
d_{i t}^{*}=\mathbf{X}_{i t}^{\prime} \boldsymbol{\theta}+\varepsilon_{i t} \geq 0
$$


The latent variable, $d_{i t}^{*}$, is not observed; only the decision to invest in no-till machinery or not to invest is known to the econometrician. Some of the variables included in $\mathbf{X}_{i t}$ that affect a farmer's decision to purchase no-till machinery may also affect the production cost. The vector $\mathbf{X}_{i t}$ should also contain some variables (called instruments) that are excluded from the cost function and play the role of identifying variables in the adoption model.

In the first stage, we estimate the probability that farmer $i$ invests in no-till machinery in year $t$ using the following Probit model:

$$
d_{i t}=F\left(\mathbf{X}_{i t}^{\prime} \boldsymbol{\theta}\right)+v_{i t}
$$

where $d_{i t}$ equals 1 if the expected net benefit $d_{i t}^{*}$ is positive, and 0 otherwise. We only observe whether the farmer owns no-till machinery or not in year $t$. We assume from now on that a farmer who invests in no-till machinery in year $\bar{t}$ will be using it from year $\bar{t}+1$ onwards, i.e. we will have $d_{i t}=1 \forall t \geq \bar{t}$. Function $F$ is the cumulative distribution of the $\varepsilon_{i t}$ error term, assumed standard normal. Maximum-likelihood provides consistent estimates of the parameter vector $\theta$. In the second stage, the predicted probability $\widehat{d_{i t}}=F\left(\mathbf{X}_{i t}^{\prime} \hat{\boldsymbol{\theta}}\right)$ is used instead of $d_{i t}$ as an explanatory variable in the cost function estimation.

\section{Description of the data and variables used in the analysis}

The data used in this study were obtained primarily from farm profitability bookkeeping records collected annually by MTT Agrifood Research Finland. The records are collected following EU accounting guidelines and provide the Finnish set of data for the European Commission's Farm Accountancy Data Network (FADN). ${ }^{\text {iv }}$ They include annual farm-level data on acreages allocated to each crop, crop yields, total variable costs and expenditures on fertilizers and plant protection, work hours, capital asset values, as well as information on 
whether the farm has a no-till drill, for approximately 900 farms located all over Finland. ${ }^{\mathrm{v}}$ These data were complemented with weather data from the Finnish Meteorological Institute; grain, fertilizer, plant protection, and fixed asset price indices from Statistics Finland; labor prices from the Information Center of the Ministry of Agriculture; and grain prices and area based subsidies from MTT Agrifood Research’s annual publication Finnish Agriculture and Rural Industries. For the purpose of this analysis, we only included farmers who were engaged primarily in crop production. Our final sample is an unbalanced panel of altogether 249 farmers in Southern Finland, Finland's main crop production region, over the 1998-2004 period and includes a total of 854 observations.

\subsection{Factors hypothesized to influence the adoption of no-till}

Typically, the adoption and use of conservation tillage practices are assumed to depend on four general types of observable variables: farm operator, biophysical and financial characteristics; and exogenous factors such as government policies and herbicide prices (see survey by Knowler and Bradshaw 2007). In line with previous research, we hypothesize that farm $i$ 's decision to invest in no-till machinery is influenced by a number of farm characteristics and exogenous factors which we now turn to.

\section{Farm and farmer characteristics}

We consider farmer's age, regularly analyzed in the literature but without agreement on the direction of its effect. Gould et al. (1989), Soule et al. (2000) and Davey and Furtan (2008) found age to have a negative effect while Warriner and Moul (1992) and Kurkalova et al. (2006) showed a positive effect. We also analyze the effect of farm size, here measured by the total area planted with grains. The findings in previous literature about the impact of farm size are also not clear. Smit and Smithers (1992), Fuglie (1999), Soule et al. (2000), Davey and 
Furtan (2008) and D’Emden et al. (2008), for example, found a positive effect. Shortle and Miranowski (1986), in contrast, established a negative effect while Nowak (1987) and Agbamu (1995) found no significant correlation between farm size and adoption of conservation tillage.

Farm type may also affect adoption of conservation tillage. We included a dummy variable that was set equal to 1 if at least $50 \%$ of the farm's production costs arose from animal related production. The time commitments necessary for maintaining animals could imply a positive relationship between animal production and adoption. Farms growing grass for their animals may also benefit from the capacity of no-till to replant grasslands without plowing in the spring if they have not survived winter. Alternatively, a negative relationship could be expected due to less time for acquiring knowledge about a new crop production technology. ${ }^{\mathrm{vi}}$

Among farm financial characteristics, we considered the total value of machinery, an index of profit performance (the ratio of the farmer's per hectare profit to the maximum per hectare profit observed in our sample in the same year), and the ratio of long term loans to total loans. Previous literature has hypothesized that farms with sufficient financial well-being are more likely to adopt conservation tillage. One would then expect the total value of machinery and profit performance to have a positive impact on no-till adoption, and the ratio of long term loans to total loans to have a negative impact. Gould et al. (1989) found a positive effect of household income and a negative effect of the debt ratio on the probability of adoption. In Warriner and Moul (1992) and Davey and Furtan (2008) the effects of net farm income and value of machinery, respectively, were not significant.

\section{Exogenous factors}


Government policies can be influential in steering farmers’ decisions (see e.g. Gardner 1990). While Finland does not have a specific program for encouraging the adoption of no-till or other conservation tillage methods, the agro-environmental program in place since 1995 aims at promoting water protection and biodiversity conservation measures. Farmers receiving payments through the program are subject to the provision that $30 \%$ of the arable area be left under plant cover in throughout the year, and area under no-till counts towards this requirement. Farmers can also receive additional payments for adopting measures not included in the basic program requirements. We consider the share of environmental subsidies in farm profit which we hypothesize to have a positive effect on the probability of adoption. Previously, Napier and Camboni (1993) found a positive impact of a state subsidy program on adoption; Traore et al. (1998) and Soule et al. (2000) in contrast found program participation to be not significant.

The role of herbicides becomes important under no-till where they are used as a substitute for weed control by tillage. D’Emden et al. (2006) found a negative impact of the change in the price of glyphosate relative to the change in the price of diesel on the probability of adoption; the impacts of the changes in the prices of two other herbicides, trifluralin and diclofop, were not significant. We consider the price of plant protectants relative to the output price as a factor explaining adoption. We expect the variable to have a negative impact. As no-till reduces the need for fuel (e.g. Lankoski et al. 2006, Knowler and Bradshaw 2007), we also consider the price of fuel relative to the output price. It is expected that the impact on adoption is positive.

Fields under no-till take longer to dry in the spring than tilled fields, and in the Finnish conditions of wet and cold soils crops can be sown later than when using conventional tillage. 
Farmers using no-till thus face a shorter growing season than those using conventional, which could decrease yields. To capture this effect, we include the average start date of the growing season in the past five years (measured in number of days since January $1^{\text {st }}$ ). Adoption of notill is expected to be less profitable in areas with a late start of the growing season, and we hence expect the start date variable to have a negative impact. We also consider the average temperature sum before July 1 in the past five years to describe temperature in the sowing period. A higher temperature sum early in the growing season indicates earlier sowing, and we expect the variable to have a positive effect on no-till adoption. Finally, two regional dummy variables control for regional characteristics not captured by the weather variables.

\subsection{Hypothesized impact of no-till on production costs and input use}

The cost function summarizes information about the technological choices and economic possibilities available to a farm. Economic theory suggests that the short run variable cost function will depend on the total output quantity and input prices, as well as the available technologies. We use grain output (y) as a quantity index measuring cereal production on each farm (including production of barley, oats, rye, and wheat). The major variable inputs for grain production in Finland are labor $(l)$, fertilizers $(f)$ and plant protection $(p)$. Thus, we include grain output and the prices of labor, fertilizer and plant protection products as factors explaining a farm's production costs and input use. We choose the price of fertilizers as the numeraire in the Translog cost function. As farm-specific variables controlling for heterogeneity in the population of farmers we include the stock of machinery $k$ and the endogenous dummy variable $d$ indicating whether or not the farm owns no-till machinery. We hypothesize that the costs and input use will be influenced by the farm's tillage technology. Numerous financial studies of conservation tillage adoption have suggested that it reduces costs for fuel and labor (e.g. Stonehouse 1997). On the other hand, farmers adopting 
conservation tillage could possibly increase their use of herbicides (see e.g. Holland 2004, Rose and Carter 2003). The overall impact on production costs is thus ambiguous but we expect a negative impact of no-till on labor and a positive effect on use of plant protection products. Unfortunately, we will not be able to measure the impact of no-till adoption on fuel use since our data do not include fuel expenditure. Finally, a farm's production costs and input use are likely to be influenced by the same observable and unobservable factors as the decision to adopt no-till. In order to correct for bias due to self-selection into the group of adopters, we construct the probability that farm $i$ has a no-till drill at time $t$ using the estimated parameters of the adoption model. We consider the total value of machinery as a proxy for the capital stock. We also include a time trend to provide a measure of technical change over the study period.

\subsection{Summary statistics}

Approximately $4 \%$ of farmers in the sample owned no-till machinery. This proportion remained almost constant over the period 1998-2004, varying between a minimum of 3.1\% in 2001 and a maximum of 5.5\% in 2003 (Table 1). ${ }^{\text {vii }}$ In what follows, farmers that own no-till machinery are considered adopters. Summary statistics (Table 2) show that on average the farmers with no-till machinery had a larger grain area and a higher per hectare grain output (measured in the value of the output) than farmers without no-till machinery. They also had on average about $23 \%$ lower variable costs, spent less time on the field, and expended less on fertilization but more on plant protection, again measured in per hectare terms.

\section{Estimation procedure and results}

\subsection{Adoption of no-till technology}


For each farm in each year in our sample, we know whether the farm owns no-till machinery or not. Farms that do own no-till machinery took the decision to invest in the machinery only once. This investment is the particular decision-making process that we want to model. Therefore, in our adoption model, a farm that owns no-till machinery is included in the sample only once, in the year the machinery was purchased, and excluded from the sample in the subsequent years (Khanna and Damon, 1999, followed a similar approach). A farm may thus appear in the sample multiple times as a non-adopter, but only once as an adopter. The dependent variable $d_{i t}$ equals zero if farm $i$ did not own no-till machinery in year $t$, and 1 if farm $i$ reported to own no-till machinery for the first time in year $t$. Since it is likely that the decision to invest in no-till machinery was made a year before the purchase, all explanatory variables are measured in year $t-1$. By using lagged explanatory factors, we also eliminate endogeneity bias.

The number of farms investing in no-till machinery is quite small in our sample - only 29 farms purchased no-till machinery over the years 1998-2004. To obtain a more balanced proportion of adopters and non-adopters than full sample would entail, the adoption model will be estimated on a choice-based sub-sample. We include all farms that purchased the machinery over the 1999-2004 period, and randomly draw 87 observations from the population of farms without no-till machinery (including farms that have not adopted in year $t$ but do so later). By over sampling observations for adopters, we enrich the sample (we now have a sample with $25 \%$ adopters and $75 \%$ non-adopters) and obtain a sufficient number of observations to estimate the probability of adoption (see Greene 2003). In order to correct the bias induced by over sampling one group of farms, we estimate the model using the weighted endogenous sampling maximum likelihood (WESML) estimator derived by Manski and Lerman (1977). The log-likelihood function is written as follows: 


$$
\ln L=\sum_{i, t} s_{i t}\left\{y_{i t} \ln F\left(\mathbf{X}_{\mathbf{i t}}^{\prime} \boldsymbol{\theta}\right)+\left(1-y_{i t}\right) \ln \left[1-F\left(\mathbf{X}_{\mathbf{i t}}^{\prime} \boldsymbol{\theta}\right)\right]\right\}
$$

where $y_{i t}$ describes the adoption decision $\left(y_{i t}=0\right.$ or $\left.y_{i t}=1\right)$, $s_{i t}=y_{i t}\left(\omega_{1} / p_{1}\right)+\left(1-y_{i t}\right)\left(\omega_{0} / p_{0}\right)$, with $\omega_{1}$ and $\omega_{0}$ the true population proportions (obtained from the representative sample of farms), and $p_{1}$ and $p_{0}$ the proportions of adopters and non-adopters in the choice-based sample. ${ }^{\text {viii }}$ The sensitivity of our results with respect to the choice-based sample will be studied in section 4.4 .

Table 3 shows the estimation results. The model is significant overall (the Wald test statistic is significant at the $10 \%$ level) even if the fit of the model is quite low (the pseudo $\mathrm{R}^{2}$ is 0.13 ). The price of plant protection relative to grain price had a statistically significant negative effect and the price of fuel relative to grain price a statistically significant positive effect on the probability of investing in no-till machinery. These signs are consistent with expectations - no-till cultivation is expected to increase the use of plant protection products and decrease the amount of machine work on the field and thus the use of fuel. The results also indicate that larger farms and younger farmers are more likely to purchase no-till machinery. Larger farms have more area to spread the capital cost over. Similarly, younger farmers have longer horizons to spread the capital costs over. Two other variables were close to significance and had signs that agreed with expectation: the positive coefficient of the profit performance index would indicate that farms performing well relative to other farms in the same line of production are more likely to adopt. The ratio of long term loans over total loans had a negative coefficient, which could suggest that farms already indebted are less likely to invest in no-till machinery. The coefficients of the average historical weather conditions (start of the growing season and sum of efficient temperature over the first half of the growing season over the past five years), environmental subsidies, region and farm type (a dummy variable 
that was set equal to 1 if at least $50 \%$ of the farm's production costs arose from animal related production) were not significantly different from zero at conventional levels.

\subsection{Impact of no-till on grain production costs and input use}

\section{Estimated cost function}

The system of equations comprised by the Translog cost function (2), and the labor and plant protection cost share equations (4) was estimated by three-stage-least squares. Unfortunately, accounting for the panel structure of the data was not possible since this would have implied losing too many observations: altogether 77 farms (which represent one third of our sample) were observed only once over the study period. Table 4 presents the estimation results for the

Translog cost function. The fit of the three equations is quite good: the $R^{2}$ for the Translog cost function, the labor cost share equation, and the plant protection cost share equation are $0.66,0.92$, and 0.67 , respectively.

\section{Cost elasticities}

Since the variable cost and the regressors are in natural logarithms and have been normalized by mean-scaling, the first-order coefficients should all be interpreted as cost elasticities evaluated at the sample mean. ${ }^{\text {ix }}$ The elasticity of the total variable cost with respect to grain production, 0.36 , has the expected positive sign and is statistically significant at the $1 \%$ level. It indicates that a $1 \%$ increase in grain production would induce a $0.36 \%$ increase in the total variable cost. The elasticities of the cost with respect to the factor prices are equivalent to the shares of each factor in the total cost. Thus, at the sample mean, labor accounts for approximately $58 \%$ of farm variable costs and plant protection for $11 \%$, which corresponds to the sample means reported in Table 2. 
Estimated change in costs and input use following no-till adoption

The predicted probability of no-till adoption has a positive but non-significant effect on total variable cost. The coefficients of the cross-effects between the predicted probability of using no-till and the input prices instead are statistically significant. These coefficients can be interpreted as the impact of using no-till on the share of input costs in total variable costs. We thus find statistical evidence that, on average, no-till decreases the share of labor costs by $20.4 \%$ and increases the share of plant protection costs in total variable costs by $8.9 \%$, all other things equal. The 95\% confidence intervals are [-38.7\%;-2.2\%] and [0.9\%;16.8\%], respectively. Consequently, our model predicts that the share of fertilizers in total variable costs would increase by $11.5 \%$, on average. These directions are as one would have expected based on financial analyses (in particular for labor and plant protection inputs). Experimental studies have indicated that the yields of wheat, barley, and oats are lower under no-till cultivation than under conventional tillage in Finland (see Table 2 in Lankoski et al., 2006). The risk of lower yields under no-till may induce farmers to increase their use of fertilizers. However, the effects on labor, plant protection and fertilizer costs seem to cancel out since the impact of using no-till on the total variable costs is not statistically different from zero. The result that there is no significant reduction in the production cost following the adoption of no-till may explain why so few farmers have decided to change the tillage practice.

Using the estimated parameters from the Translog cost function, we computed the estimated change in input use following no-till adoption. For each input factor $j$ (labor, plant protection, and fertilizers), the derived demand $q_{j}$ is computed as follows: 


$$
\begin{aligned}
& q_{j}=\frac{\partial C}{\partial w_{j}}=\frac{\partial \ln C}{\partial w_{j}} \times \frac{C}{w_{j}}=\left(\widehat{\lambda_{j}}+\sum_{m} \widehat{\lambda_{j m}} \ln w_{m}+\widehat{\rho_{j}} \ln y+\sum_{r} \widehat{\eta_{j r}} \ln z_{r}\right) \times \\
& \left(\begin{array}{l}
\widehat{\beta_{0}}+\widehat{\beta} \ln y+\sum_{j} \widehat{\lambda_{j}} \ln w_{j}+\sum_{r} \widehat{\gamma_{r}} \ln z_{r}+\frac{1}{2} \widehat{\beta_{y y}} \ln y_{t} \ln y_{t}+\frac{1}{2} \sum_{j} \sum_{m} \widehat{\lambda_{j m}} \ln w_{j} \ln w_{m} \\
+\frac{1}{2} \sum_{r} \sum_{s} \widehat{\gamma_{r S}} \ln z_{r} \ln z_{s}+\sum_{j} \widehat{\rho_{j}} \ln y \ln w_{j}+\sum_{r} \widehat{\kappa_{r}} \ln y \ln z_{r}+\sum_{j} \sum_{r} \widehat{\eta_{j r}} \ln w_{j} \ln z_{r}
\end{array}\right) \times \frac{1}{w_{j}} .
\end{aligned}
$$

The results suggest that adoption of conservation tillage decreases demand for labor by 35\% on average, and increases the use of fertilizers and plant protection products by $39 \%$ and $98 \%$, respectively. These effects are statistically significant. The expected change in input use varies across the sample of farms. Figure 1 shows the percentage change in per hectare input use for five farm size classes. The smallest farms are expected to increase the use of plant protection by more than $150 \%$ after no-till adoption, which is markedly more than for the other size classes. The expected reduction in labor for the smallest farms, in contrast, is notably below the expected reduction for the other groups of farms. On the largest farms, adoption of no-till is expected to induce a larger reduction in labor and a smaller increase in use of fertilizers and plant protection. These results may reflect differences in farm management; the larger farms may be more professionally managed and more knowledgeable in terms of the use on no-till and adjustments required by a change in the tillage practice.

We also compared predictions for the changes in the different input costs obtained (i) by simply computing the average per hectare expenditure for each input in the group of nonadopters and adopters, using observed expenditures, and (ii) by computing the average predicted per hectare expenditures using the parameter estimates from our two-stage model, thus accounting for the fact that there are likely to be farm-specific factors present that affect both the decision to adopt no-till, and the production cost. The results in Table 5 indicate that the simple approach (i.e. comparison of group means) could indeed lead to erroneous 
conclusions. In the case of labor and plant protection, the directions of the changes produced by the two approaches are similar but the magnitudes differ notably in the case of plant protection: comparing the group means indicates that no-till adoption increases the expenditure on plant protection products by $20 \%$; the prediction from the model with sample selection correction instead is $90 \%$. For fertilizers, even the directions of change produced by the two approaches differ. The simple group means comparison predicts that expenditure on fertilizers would decrease, while the two-stage approach indicates that expenditure on fertilizers increases markedly after no-till adoption. The results confirm that a simple group means comparison is only appropriate when adopters and non-adopters have comparable characteristics except for their technology choice (or, equivalently, if the choice to adopt notill was completely random). Indeed, the policy implications of the two sets of results are quite different. Using expenditure as a proxy for input use, the two-stage approach makes notill environmentally less desirable than the simple approach; increased use of plant protection products and fertilizers could imply increased runoffs of both plant protection agents and nutrients. We next turn to these environmental impacts in some more detail.

\subsection{Environmental impact simulation}

We used the estimated cost function parameters to derive labor, fertilizer and plant protection demands for farms with and without no-till technology. We then combined the predicted input demands with functions predicting nitrogen, phosphorus and herbicide loads from land in grain production to simulate the environmental impact of tillage technology. For comparison, we also computed the loads with input levels predicted by the simple approach of observed group means. We used the same nutrient and herbicide loading models as Lankoski et al. (2006), compiled from a number of natural science studies, but abstracted away from buffer strips as a measure to mitigate loading. The nutrient model has also been applied by Helin et 
al. (2006). Lankoski et al. considered a model parameterization based on results for a relatively steeply sloped and therefore particularly erosion prone experimental field in SouthWestern Finland. Helin et al. applied a parameterization that was calibrated based on observed agricultural practices and nutrient loads for Southern Finland. ${ }^{\mathrm{x}}$ The soil type in both parameterizations is clay, which is predominant in Southern Finland. The Helin et al. parameterization can be considered more representative of the conditions in our study region as it is based on observed values for an approximately overlapping area, with a slope profile representative of Southern Finland. We next describe the nutrient and herbicide loading models briefly; for a more detailed description, we refer the reader to Lankoski et al. (2006) or Helin et al. (2006).

\section{Nutrient loading model}

We consider a compound fertilizer with $20 \%$ nitrogen and $3 \%$ phosphorus content, as was done by Lankoski et al. Given a predicted fertilizer quantity $x_{k}$ for tillage $k$, the applied nitrogen and phosphorus are $N_{k}=0.20 x_{k}$ and $P_{k}=0.03 x_{k}$, respectively. Using a nitrogen loading function by Simmelsgaard (1991), the nitrogen load in $\mathrm{kg} / \mathrm{ha}$ is given by

$$
z_{N, k}=\phi_{k} \exp \left\{0.71\left[N_{k} / \bar{N}_{k}-1\right]\right\}
$$

where $\phi_{k}$ is a parameter capturing technology-based differences in loads and $\bar{N}_{k}$ a reference fertilization level. Two distinct forms of phosphorus, dissolved and particulate, are present in agricultural loads. Drawing on Saarela et al. (1995) and Uusitalo and Jansson (2002), the dissolved phosphorus load is given by

$$
z_{D P, k}=\sigma_{k} \cdot \psi_{k}\left[2\left(\theta+0.01 P_{k}\right)-1.5\right] \cdot 10^{-4}
$$

where $\psi_{k}$ is runoff volume, $\sigma_{k}$ a technology-based parameter, and $\theta$ measures soil phosphorus level. The particulate phosphorus load in turn is given by 


$$
z_{P P, k}=\Delta_{k} \cdot \zeta_{k}\left\{250 \ln \left[\theta+0.01 P_{k}\right]-150\right\} \cdot 10^{-6},
$$

where $\zeta_{k}$ is erosion and $\Delta_{k}$ a technology-base parameter. We consider two sets of parameter values for (9) to (11): one from Lankoski et al. (2006) (Table 6), which corresponds to environmentally sensitive conditions (above-average erosion and soil phosphorus level), and one from Helin et al. (2006) (Table 7), which corresponds to average conditions for SouthWestern Finland (the main grain producing region). From Lankoski et al. (2006), the damage from agricultural nutrient loading (euros/kg) is

$$
35\left[z_{N, k}+7.2\left(z_{P P, k}+z_{D P, k}\right)\right]
$$

where phosphorus has been transformed into nitrogen equivalents through multiplication by the Redfield ratio 7.2. The price of the compound fertilizer was set equal to its 2003 level.

\section{Herbicide loading model}

As in Lankoski et al. (2006), we assume that glyphosate is applied only under no-till as preemergence control for quackgrass, at the standard application rate of $1500 \mathrm{~g} / \mathrm{ha}$, and that MCPA is applied under both technologies as a continuous choice variable. From Lankoski et al. (2006), the total glyphosate load is $4.23 \mathrm{~g} /$ ha when the impact of buffer strips is removed, and the price of glyphosate 18.9 euros/ha (in year 2002 prices). The use of MCPA is optimized. For the case of no-till, we derive MCPA demand by first subtracting expenditure on glyphosate from the predicted expenditure on plant protection products, and then divide by the MCPA price, 6.25 euros/kg (from Lankoski et al., 2006, in year 2002 prices). For the case of conventional tillage, we assume that all expenditure on plant protection products is attributable to MCPA. The MCPA load into the environment is described by the following equation, adapted by Lankoski el al. (2006) from Kreuger and Törnqvist (1998):

$$
\log Z_{M C P A}=1.055+1.1 \log x,
$$


where $Z_{M C P A}$ is MCPA load and $x$ is MCPA application (kg/ha). As Lankoski et al. (2006), we use the damage estimate for herbicide loading (here the sum of glyphosate and MCPA) suggested by Siikamäki (1997), 0.1893 euros/g.

\section{The impact of tillage technology on nutrient and herbicide runoffs}

We simulated the herbicide and nutrient application rates and the associated runoffs based on observed and predicted values for year 2004 (all regions). We assumed that the entire arable area of a farm is under no-till if the farm owns no-till machinery. Table 8 shows the results for the per hectare application rates predicted by our model for the estimated cost function parameters. We also report the lower and upper bounds of the 95\% confidence intervals for the total environmental damage under no-till and conventional tillage. Our model predicts that no-till increases the use of MCPA; in addition, glyphosate is only applied under no-till. Consequently, the total herbicide load almost doubles under no-till. Nitrogen and phosphorus application also both increase. For the load parameters from Lankoski et al. (2006), no-till nevertheless markedly reduces the nitrogen and particulate phosphorus loads. Even though the dissolved reactive phosphorus load increases to more than threefold, the nitrogen load and consequently the total nutrient load measured in nitrogen equivalents decrease markedly. In total, for the erosion-prone case described by the Lankoski et al. parameters, no-till produces substantial environmental benefits. The difference between total environmental damages under conventional tillage and no-till is statistically significant at the $95 \%$ level. ${ }^{\mathrm{xi}}$ The empirical estimate for the damage from herbicide loading is very small relative to the damage from nutrient loading, so that even though the herbicide load doubles, the total environmental damage decreases by 34\% following no-till adoption. As stated by Lankoski et al. (2006), the small role of herbicide damage reflects peculiarities of Finnish agriculture, where herbicide use is minor. For the parameters from Helin et. al (2006), no-till does not affect the nitrogen 
load from a given nitrogen surplus (parameter $\phi_{k}$ ). Thus, even while no-till does reduce the particulate phosphorus load, the increase in nitrogen load attributable to increased application rate, together with the increase in the dissolved phosphorus load, more than offset the reduction in the particulate phosphorus load. Both the herbicide and total nitrogen equivalent nutrient loads increase, resulting in a $27 \%$ increase in the environmental damage. However, the difference between the total damages under conventional tillage and no-till is not statistically significant. ${ }^{\text {xii }}$ The expected impact of doing no-till in average conditions is thus less clear and cannot be confirmed from our data.

Table 9 reports the environmental damage that corresponds to the average use of fertilizers and plant protection agents (i.e. the sample mean computed from the observed data). For the parameters from Lankoski et al. (2006), using the sample averages exaggerates the environmental benefit of no-till, by attributing to it a significant reduction in both MCPA and fertilizer application. The resulting reduction in environmental damage would be $45 \%$, as opposed to the $34 \%$ obtained with the predicted use of fertilizers and plant protection products. For the parameters from Helin et al. (2006), the analysis based on observed values would indicate that no-till reduces the total environmental damage. Here the simple approach thus yields results that are both quantitatively and qualitatively misleading.

\subsection{Sensitivity analysis}

Finally, we tested whether the estimated impact of no-till on input costs and environmental damage is sensitive to the choice-based sample used at the first stage of the econometric procedure. We drew 100 different choice-based samples, estimated 100 Translog cost functions, and computed the corresponding 100 environmental damage scenarios under no-till and under conventional tillage. 
No-till reduced the share of labor costs in 84 out of 100 cases and increased the share of plant protection costs in 91 out of 100 cases. Estimated coefficients with a sign that did not conform with the base case results discussed in section 4.2 were in general not significant. On average, in our 100 replications, no-till decreased the share of labor costs by $12 \%$ and increased the share of plant protection costs and fertilizer costs by $6 \%$ and $5.5 \%$ respectively. The magnitude of these effects is slightly lower than the magnitude of the coefficients shown in Table 4, but the sensitivity analysis shows that direction of the impact of no-till on labor, plant protection, and fertilizer costs is robust to the choice of the random sub-sample.

The corresponding 100 replications of environmental damage were computed with the parameters from Helin et al. (2006), since they are more representative of the average conditions in Southern Finland than the Lankoski et al. (2006) parameters. The total damage under conventional tillage was 924 euros per hectare on average in the 100 replications (standard deviation of 8) while the total damage under no-till was 1,033 euros per hectare on average (standard deviation of 157). In all cases, the confidence intervals for the damages overlapped, indicating that the two damages are not statistically different. As expected, the estimated damage (especially under no-till) was found sensitive to the choice-based sample. All in all, the sensitivity analysis confirms our main result that the environmental impact of no-till in average conditions is ambiguous.

\section{Discussion}

This paper evaluates the impact of no-till on farms' production costs and on their use of fertilizers, plant protection products, and labor based on observed behavior. We find no statistically significant effect of no-till on the overall production costs, which may explain 
why no-till is not very widely spread in Finland. Farms' input use instead was found to change; no-till increased the use of both plant protection products and fertilizers but decreased the use of labor. An environmental impact simulation indicated that the increase in the use of these inputs would be offset by the reduction in erosion and particulate phosphorus loading in the case of environmentally sensitive conditions, but not in average conditions. The result is in line with the findings by Lankoski et al. (2006) that no-till provides environmental benefits in the form of overall reductions in environmental damage from nutrient and herbicide runoffs in environmentally sensitive areas.

Unfortunately, working with the Translog cost function allows us to predict only the impact of no-till adoption on input demands, not on yields. ${ }^{\text {xiii }}$ Thus, we are only able to assess the impact of no-till on the environmental performance of farms, and on their costs, but not on their overall economic performance. With the yield impact missing, we are not able to predict whether no-till would bring along overall advantages to the society. However, our findings indicate that no-till is more likely to be beneficial on the whole in environmentally sensitive areas, where the substantial environmental benefits could offset even potential yield losses, than in average conditions. Overall results do not support advocating no-till as an environmentally friendly tillage practice in the Finnish conditions in general but rather as a targeted conservation measure for highly erodible soils.

One limitation of our data is that they only indicate whether a farm owns no-till machinery or not, and we were thus forced to use ownership as a proxy for no-till adoption. Farms may also use contractors instead of investing in the no-till machinery. Thus, there may be farms in our sample classified as non-adopters that are actually using no-till. Farms that do own no-till machinery may also have only a part of their grain area under no-till. These limitations, 
however, are likely to influence the magnitude rather than the sign of our parameters estimates. A more accurate prediction of the economic and environmental impacts of no-till would be obtained if information were available on the actual field area in no-till cultivation. Another limitation of our study is that, due to the unavailability of crop-specific input data (which is typical in production-side analyses of agriculture), we estimated a single cost function for aggregate grain production. We are thus only able to make predictions about the impact of no-till on input use at the aggregate level, not at the level of individual crops.

Finally, a full assessment of the impact of no-till cultivation on the environment should also take into account the impact of no-till on greenhouse gas emissions. Indeed, no-till cultivation has been shown to reduce the release of carbon dioxide into the atmosphere because of reduced fuel consumption and the ability of unplowed soils to better retain carbon. However, preliminary results for Finland indicate that while no-till does reduce carbon dioxide emissions, in the wet soil conditions typical of Finland it may in fact increase nitrous oxide emissions; the impact of no-till on the total greenhouse gas emissions from crop production is thus unclear (Regina and Alakukku 2008). As only scarce measurements on the impact of notill on greenhouse gas emissions in Finnish conditions are available for the time being, we were not able to include this component in our study. 


\section{Appendix}

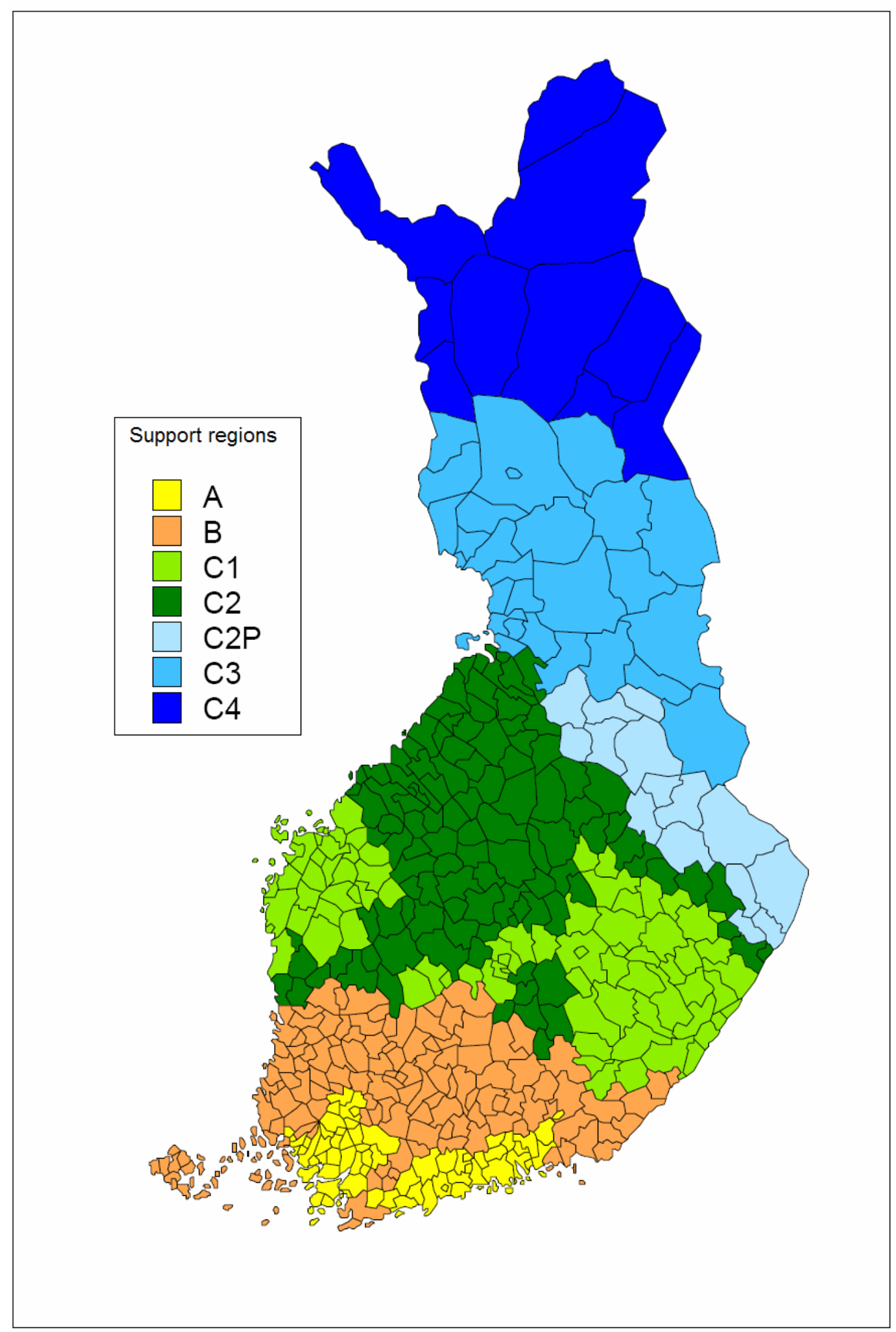




\section{References}

Agbamu, J.U. (1995). Analysis of Farmers' Characteristics in Relation to Adoption of Soil Management Practices in the Ikorodu Area of Nigeria. Japanese Journal of Tropical Agriculture 39(4): 213-222.

Beattie, B.R., and Taylor, C.R. (1985). The economics of production. John Wiley and Sons, Australia.

Caves, D.W., Christensen, L.R., and Swanson, J.A. (1981). Productivity Growth, Scale Economies, and Capacity Utilization in U.S. Railroads. The American Economic Review, 71 (5): 994-1002.

Christensen, L.R., Jorgenson, D.W., and Lau, L.J. (1973). Transcendental Logarithmic Production Frontiers. Review of Economics and Statistics, 55: 28-45.

Clark, R.T., J.B. Johnson, and J. Brundson (1994). "Economics of Residue Management," in Crop Residue Management to Reduce Erosion and Improve Soil Quality: Northern Great Plains Region. W.C. Moldenhauer and A.L. Black, (eds.) U.S. Dept. Agr., Agr. Res. Serv., Conservation Research Report No. 38.

D’Emden, F.H., Llewellyn, R.S. and Burton, M.P. (2006). Adoption of Sonservation Tillage in Australian Cropping Regions: An Application of Duration Analysis. Technological Forecasting and Social Change 73: 630-647.

D’Emden, F.H., Llewellyn, R.S. and Burton, M.P. (2008). Factors Influencing Adoption of Conservation Tillage in Australian Cropping Regions. The Australian Journal of Agricultural and Resource Economics 52: 169-182.

Davey, K. A. and Furtan, W. H. (2008). Factors That Affect the Adoption Decision of Conservation Tillage in the Prairie Region of Canada. Canadian Journal of Agricultural Economics 56: 257-275. 
Fox, G., A. Weersink, G. Sarwar, S. Duff, and B. Deen (1991). Comparative Economics of Alternative Agricultural Production Systems: A Review. Northeastern Journal of Agricultural and Resource Economics 30(1).

Fuglie, K.O. (1999). Conservation Tillage and Pesticide Use in the Cornbelt. Journal of Agricultural and Applied Economics 31(1): 133-147.

Gardner, B.L. (1990). The Economics of Agricultural Policies. McGraw-Hill, Toronto, Canada.

Gould, B.W., Saupe, W.E. and Klemme, R.M. (1989). Conservation Tillage: the Role of Farm and Operator Characteristics and the Perception of Soil Erosion. Land Economics 65(2): 167-182.

Greene, W.H. (2003). Econometric Analysis. Prentice Hall, 5th Edition.

Helin, J., Laukkanen, M. and Koikkalainen, K. (2006). Abatement Costs for Agricultural Nitrogen and Phosphorus Loads: A Case Study of Crop Farming in SouthWestern Finland. Agricultural and Food Science, 15(4): 351-374.

Holland, J. (2004). The Environmental Consequences of Adopting Conservation Tillage in Europe: Reviewing the Evidence. Agriculture, Ecosystems and Environment 103: $1-25$.

Khanna, M., and L. A. Damon (1999). EPA’s Voluntary 33/50 Program: Impact on Toxic Releases and Economic Performance of Firms. Journal of Environmental Economics and Management, 37, 1-25.

Knowler, D. and Bradshaw, B. (2007). Farmer's Adoption of Conversation Agriculture: A Review and Synthesis of Recent Research. Food Policy, 32: 25-48.

Koundouri, P., Laukkanen, M., Myyrä, S. and Nauges, C. (2009). The Effects of EU Agricultural Policy Changes on Farmers’ Risk Attitudes. European Review of Agricultural Economics, 36(1): 53-77. 
Kreuger J. and Törnqvist, L. (1998). Multiple regression analysis of pesticide occurrence in Streamflow Related to Pesticide Properties and Quantities Applied. Chemosphere 37(2): 189-207.

Kurkalova, L., Kling, C. and Zhao, J. (2006). Green Subsidies in Agriculture: Estimating the Adoption Costs of Conservation Tillage from Observed Behavior. Canadian Journal of Agricultural Economics 54: 247-267.

Lankoski, J., Ollikainen, M. and Uusitalo, P. (2006). No-till Technology: Benefits to Farmers and the Environment? Theoretical Analysis and Application to Finnish Agriculture. European Review of Agricultural Economics 33(2): 193-221.

Manski, C.F. and S.R. Lerman (1977). The Estimation of Probabilities from Choice Based Samples. Econometrica, 45(8), 1977-1988.

McLaughlin, A., Mineau, P. (1995). The impact of agricultural practices on biodiversity. Agriculture, Ecosystems and Environment 55, 201-212.

Napier, T.L. and Camboni, S.M. (1993). Use of Conventional and Conservation Practices among Farmers in the Scioto River Basing of Ohio. Journal of Soil and Water Conservation 48(3): 231-237.

Nowak, P.J. (1987). The Adoption of Agricultural Conservation Technologies: Economic and Diffusion Explanations. Rural Sociology 52(2): 208-220.

Puustinen, M., Koskiaho, J. and Peltonen, K. (2005). Influence of cultivation methods on suspended solids and phosphorus concentrations in surface runoff on clayey sloped fields in boreal climate. Agriculture, Ecosystems and Environment 105, $565-579$.

Regina, K. and Alakukku, L. (2008). No-till may increase greenhouse gas emissions (In Finnish). Agricultural Science -newsletter. March 10, 2008: 10. Agrifood Research Finland. 
Rose, S.C., Carter, A.D., (2003). Agrochemical leaching and water contamination. In: GarciaTorres, L., Benites, J., Martinez-Vilela, A., Holgado-Cabrera, A. (Eds.), Conservation agriculture: environment, farmers experiences, innovations, socioeconomy, policy. Kluwer Academic, Dordrecht, Netherlands, pp. 417-424.

Saarela, I., Järvi, A., Hakkola, H. and Rinne, K. (1995). Phosphorus Fertilizer Trials, 19771994: Effects of the Rate of Annual Phosphorus Application on Soil Fertility and Yields of Field Crops in Long-term Field Experiments (In Finnish, with an English summary). Agrifood Research Finland, Bulletin 16/95.

Sandretto, C. and Payne, J. (2006). Soil Management and Conservation. In Wiebe, K. and Gollehon, N. (eds), Agricultural Resources and Environmental Indicators. Economic Information Bulletin No. (EIB-16) , July 2006, USDA Economic Research Service. (http://www.ers.usda.gov/publications/arei/eib16/).

Shephard, R.W. (1953). Cost and Production Functions. Princeton: Princeton University Press.

Shortle, J.S. and Miranowski, J.A. (1986). Effects of Risk Perceptions and Other Characteristics of Farmers and Farm Operations on the Adoption of Conservation Tillage Practices. Applied Agricultural Research 1(2): 85-90.

Siikamäki, J. (1997). The Economic Value of Decreased Use of Pesticides? A Contingent Valuation study on willingness to pay (In Finnish). Helsinki: Agricultural Economics Research Institute Research Report, 217

Simmelsgaard, S.E. (1991). Estimation of Nitrogen Leakage Functions - Nitrogen Leakage as a Function of Nitrogen Applications for Different Crops on Sandy and Clay Soils. In: Rude, S. (ed.). Nitrogen Fertilizers in Danish Agriculture - Present and Future Application and Leaching, (In Danish, with an English summary.). Copenhagen: Institute of Agricultural Economics Report 62 pp. 135-150. 
Smit, B. and Smithers, J. (1992). Adoption of Soil Conservation Practices: an Empirical Analysis in Ontario, Canada. Land Degradation and Rehabilitation 3(1), 1-14.

Soileau, J. M., Touchton, J. T., Hajek, B. F. and Baglio, J. V. (1994). Sediment, nitrogen, and phosphorus runoff with conventional- and conservation tillage cotton in a small watershed. Journal of Soil and Water Conservation 48: 449-457.

Soule, M.J., Tegene, A. and Wiebe, K.D. (2000). Land Tenure and the Adoption of Conservation Practices. American Journal of Agricultural Economics 82(4): 993-1005.

Stonehouse, P.D. (1997). Socio-economics of alternative tillage systems. Soil and Tillage Research 43 (1-2), 109-130.

Tattari, S., Bärlund, I., Rekolainen, S., Posch, M., Siimes, K., Tuhkanen, H. R. and Yli Halla, M. (2001). Modeling Sediment Yield and Phosphorus Transport in Finnish Clayey Soils. Transactions of the American Society of Agricultural Engineers 44: 297-307.

Traore, N., Landry, R. and Amara, N. (1998). On-farm Adoption of Conservation Practices: the Role of Farm and Farmer Characteristics, Perceptions, and Health Hazards. Land Economics 74(1): 114-127.

Uri, N.D. (1998). The role of public policy in the use of conservation tillage in the USA. Science of the Total Environment 216, 89-102.

Uusitalo, R., and Jansson, H. (2002). Dissolved Reactive Phosphorus in Runoff Assessed by Soil Extraction with an Acetate Buffer. Agricultural and Food Science in Finland 11: 343-353.

Warriner, G.K. and Moul, T.M. (1992). Kinship and Personal Communication Network Influences on the Adoption Agriculture Conservation Technology. Journal of Rural Studies 8(3): 279-291. 
Zellner, A. (1962). An Efficient Method of Estimating Seemingly Unrelated Regressions and Tests for Aggregation Bias. Journal of the American Statistical Association, 58: 977-992. 


\section{Tables}

Table 1: Farms that own no-till machinery (854 observations)

\begin{tabular}{lcc}
\hline Year & $\begin{array}{c}\text { Total number } \\
\text { of farmers }\end{array}$ & $\begin{array}{c}\text { Farmers owning no-till } \\
\text { machinery (\%) }\end{array}$ \\
\hline 1998 & 124 & 3.2 \\
1999 & 114 & 3.5 \\
2000 & 122 & 3.3 \\
2001 & 127 & 3.1 \\
2002 & 118 & 4.2 \\
2003 & 128 & 5.5 \\
2004 & 121 & 4.1 \\
& & \\
\hline
\end{tabular}


Table 2: Summary statistics - mean levels

\begin{tabular}{|c|c|c|c|}
\hline & $\begin{array}{l}\text { Farmers } \\
\text { without no-till } \\
\text { machinery (\%) }\end{array}$ & $\begin{array}{c}\text { Farmers with } \\
\text { no-till } \\
\text { machinery (\%) }\end{array}$ & $\begin{array}{c}\text { Outcome of } \\
\text { mean } \\
\text { comparison } \\
\text { test }^{(\mathrm{d})}\end{array}$ \\
\hline Number of observations & 821 & 33 & \\
\hline Area planted with grain (ha) & 40 & 84 & $(* * *)$ \\
\hline Grain output (euro/ha/year) $^{(a)}$ & 346 & 420 & $(* * *)$ \\
\hline Total variable costs for crop production (euro/ha/year) ${ }^{(\mathrm{b})}$ & 456 & 350 & (n.s.) \\
\hline Cost of labor in the field (hours/ha/year) & 32 & 22 & (n.s.) \\
\hline Cost of labor in the field (euro/ha/year) & 280 & 200 & (n.s.) \\
\hline Share of labor in total variable costs & 0.59 & 0.59 & (n.s.) \\
\hline Cost for fertilizers (euro/ha/year) ${ }^{(\mathrm{c})}$ & 115 & 86 & (n.s.) \\
\hline Share of fertilizers in total variable costs & 0.27 & 0.22 & $(*)$ \\
\hline Cost for plant protection (euro/ha/year) ${ }^{(\mathrm{c})}$ & 44 & 52 & (n.s.) \\
\hline Share of plant protection in variable costs & 0.10 & 0.15 & $(* * *)$ \\
\hline
\end{tabular}

(a) Grain output corresponds to the total value of production of all crops (measured in constant 2000 euros).

(b) Variable costs include cost of fertilizers, plant protection, and labor in the field.

(c) Costs for fertilizers and plant protection have been deflated by the appropriate price index.

(d) *, **, *** indicates that the mean levels for the two groups of farmers are statistically different at the 1, 5 and $10 \%$ level, respectively. n.s. indicates that the difference between the two means is statistically non-significant. 
Table 3. WESML estimation results for no-till adoption

\begin{tabular}{|c|c|c|c|}
\hline & Coef. & $\begin{array}{l}\text { Robust } \\
\text { Std. Err. }\end{array}$ & $\mathrm{P}>\mathrm{Z}$ \\
\hline Constant & 13.540 & 10.969 & 0.217 \\
\hline Price for plant protection / grain price & $-12.060 *$ & 6.919 & 0.081 \\
\hline Price for fuel / grain price & $1.493 * *$ & 0.756 & 0.048 \\
\hline Total area planted with grain (ha) & $0.007 *$ & 0.004 & 0.105 \\
\hline Total value of machinery (euros) & 0.000 & 0.000 & 0.734 \\
\hline Farmer's age & $-0.033 * *$ & 0.013 & 0.013 \\
\hline Environmental subsidies $^{(\mathrm{a})} /$ profit & -0.047 & 0.047 & 0.316 \\
\hline Index of profit performance ${ }^{(b)}$ & 0.833 & 0.543 & 0.125 \\
\hline Long term loans / total loans & -0.774 & 0.549 & 0.159 \\
\hline $\begin{array}{l}\text { 5-past-year average of the start of the growing } \\
\text { season (in number of days since January } 1 \text { ) }\end{array}$ & -0.006 & 0.032 & 0.847 \\
\hline $\begin{array}{l}\text { 5-past-year average of the sum of efficient } \\
\text { temperature before July } 1 \text {, in Celsius degrees }\end{array}$ & -0.004 & 0.005 & 0.438 \\
\hline More than $50 \%$ of costs due to animal production ${ }^{(\mathrm{c})}$ & 0.177 & 0.222 & 0.426 \\
\hline Dummy for region $\mathrm{B}^{(\mathrm{d})}$ & -0.330 & 0.252 & 0.190 \\
\hline Dummy for region C2 & -0.012 & 0.353 & 0.973 \\
\hline Number of observations & 116 & & \\
\hline Pseudo $\mathrm{R}^{2}$ & 0.13 & & \\
\hline
\end{tabular}

(a) Environmental subsidies are given to farmers to compensate them for activities aimed at lowering the environmental impact of farming.

(b) The index of profit performance is the ratio of farmer's profit over maximum profit per hectare obtained in the same line and same year.

(c) This is an indicator variables which takes the value of 1 if the share of costs due to animal production in total variable costs is greater than $50 \%$.

(d) See map in Appendix. 
Table 4. Estimation results for the Translog cost function (three-stage-least squares estimator)

\begin{tabular}{|c|c|c|c|}
\hline Variable & Coefficient $^{(\mathrm{a})}$ & Std. Err. & $\mathrm{P}>\mathrm{z}$ \\
\hline Constant & $-0.076^{*}$ & 0.044 & 0.083 \\
\hline Grain output & $0.364 * * *$ & 0.032 & 0.000 \\
\hline Price of labor & $0.581 * * *$ & 0.007 & 0.000 \\
\hline Price of plant protection & $0.108 * * *$ & 0.003 & 0.000 \\
\hline Total value of machinery (euros) & $0.297 * * *$ & 0.035 & 0.000 \\
\hline Predicted probability of no-till & 0.238 & 0.529 & 0.653 \\
\hline Grain output x grain output & $0.186 * * *$ & 0.024 & 0.000 \\
\hline Price of labor $\mathrm{x}$ price of labor & $0.164 * * *$ & 0.030 & 0.000 \\
\hline Price of plant protection $\mathrm{x}$ price of plant protection & -0.060 & 0.041 & 0.144 \\
\hline Machinery x machinery & $0.142 * * *$ & 0.024 & 0.000 \\
\hline Predicted probability of no-till x predicted probability of no-till & -0.043 & 0.690 & 0.950 \\
\hline Grain output x price of labor & $-0.047 * * *$ & 0.007 & 0.000 \\
\hline Grain output x price of plant protection & $0.018^{* * *}$ & 0.003 & 0.000 \\
\hline Grain output x machinery & $-0.142 * * *$ & 0.020 & 0.000 \\
\hline Price of labor x price of plant protection & $-0.074 * * *$ & 0.019 & 0.000 \\
\hline Price of labor x machinery & -0.010 & 0.007 & 0.134 \\
\hline Price of plant protection $\mathrm{x}$ machinery & $0.007 * *$ & 0.003 & 0.022 \\
\hline Grain output x predicted probability of no-till & -0.087 & 0.390 & 0.823 \\
\hline Price of labor x predicted probability of no-till & $-0.204 * *$ & 0.093 & 0.028 \\
\hline Price of plant protection x predicted probability of no-till & $0.089 * *$ & 0.041 & 0.028 \\
\hline Machinery x predicted probability of no-till & 0.236 & 0.459 & 0.607 \\
\hline Trend & $-0.039 * * *$ & 0.009 & 0.000 \\
\hline
\end{tabular}

(a) $*, * *, * * *$ indicates statistical significance at the 1, 5 and $10 \%$ level, respectively. 
Table 5. Comparison of per hectare input costs (euros) between conventional tillage and notill: group means versus predictions from the two-stage model correcting for self selection

\begin{tabular}{lcccccc}
\hline & \multicolumn{2}{c}{ Labor } & \multicolumn{2}{c}{ Plant protection } & \multicolumn{2}{c}{ Fertilizers } \\
\hline & $\begin{array}{l}\text { Group } \\
\text { means }\end{array}$ & $\begin{array}{c}\text { From the } \\
\text { model }\end{array}$ & $\begin{array}{c}\text { Group } \\
\text { means }\end{array}$ & $\begin{array}{c}\text { From the } \\
\text { model }\end{array}$ & $\begin{array}{c}\text { Group } \\
\text { means }\end{array}$ & $\begin{array}{c}\text { From the } \\
\text { model }\end{array}$ \\
\hline $\begin{array}{l}\text { Conventional tillage } \\
\text { No-till }\end{array}$ & 280 & 252 & 44 & 40 & 115 & 123 \\
$\begin{array}{l}\text { Percentage change } \\
\text { after adoption of no-till }\end{array}$ & $\mathbf{- 2 9}$ & 167 & 52 & 77 & 86 & 171 \\
\hline
\end{tabular}

\section{Notes:}

"Group means": we computed the average expenditure per hectare for each input in the group of farmers using conventional tillage and in the group of farmers doing no-till using observed expenditures.

"From the model": we computed the average predicted expenditure per hectare for each input, if all farmers use conventional tillage, and if all farmers use no-till. 
Table 6. Nutrient runoff parameters used by Lankoski et al. (2006), based on Puustinen et al. (2005). CT=conventional tillage, NT=no-till.

\begin{tabular}{lcccccc}
\hline & \multicolumn{2}{c}{ Wheat } & \multicolumn{2}{c}{ Barley } & \multicolumn{2}{c}{ Oats } \\
\hline Parameter & CT & NT & CT & NT & CT & NT \\
$\phi$ & 15 & 8 & 15 & 8 & 15 & 8 \\
$\bar{N}$ & 100 & 100 & 100 & 100 & 100 & 100 \\
$\zeta$ & 2100 & 620 & 2100 & 2100 & 2100 & 2100 \\
$\psi$ & 234 & 233 & 234 & 233 & 234 & 233 \\
$\Delta$ & 3.03 & 3.13 & 3.03 & 3.03 & 3.03 & 3.03 \\
$\sigma$ & 0.655 & 2.28 & 0.655 & 2.28 & 0.655 & 2.28 \\
$\theta$ & 18.6 & 18.6 & 18.6 & 18.6 & 18.6 & 18.6 \\
\hline
\end{tabular}

Table 7. Calibrated nutrient runoff parameters from Helin et al. (2006).

$\mathrm{CT}=$ conventional tillage, $\mathrm{NT}=$ no-till.

\begin{tabular}{lcccccccc}
\hline & \multicolumn{3}{c}{ Wheat } & \multicolumn{2}{c}{ Winter wheat } & \multicolumn{2}{c}{ Barley } & \multicolumn{2}{c}{ Oats } \\
\hline Parameter & CT & NT & CT & NT & CT & NT & CT & NT \\
$\phi$ & 24 & 24 & 21 & 21 & 21 & 21 & 12 & 13 \\
$\bar{N}$ & 100 & 100 & 120 & 120 & 90 & 90 & 90 & 90 \\
$\Delta \cdot \zeta$ & 235 & 140 & 226 & 223 & 220 & 125 & 224 & 129 \\
$\sigma \cdot \psi$ & 326 & 349 & 355 & 363 & 316 & 322 & 323 & 347 \\
$\theta$ & 10.6 & 10.6 & 10.6 & 10.6 & 10.6 & 10.6 & 10.6 & 10.6 \\
\hline \multicolumn{2}{l}{ Notes: Helin et al. (2006) collapse (1) runoff volume and the technology based difference in dissolved } \\
phosphorus runoff, $\psi$ & $\psi$ and $\sigma$, into one parameter, and (2) erosion and technology based difference in \\
particulate phosphorus runoff, $\zeta$ and $\Delta$, into one parameter.
\end{tabular}


Table 8. Simulated nutrient and herbicide loads from the estimated input use.

$\mathrm{CT}=$ conventional tillage, $\mathrm{NT}=$ no-till.

\begin{tabular}{|c|c|c|c|c|c|}
\hline & & \multicolumn{2}{|c|}{$\begin{array}{l}\text { Lankoski et al. } \\
\text { (2006) }\end{array}$} & \multicolumn{2}{|c|}{ Helin et al. (2006) } \\
\hline & & $\mathrm{CT}$ & NT & CT & NT \\
\hline Glyphosate application & (kg/ha) & 0 & 1.5 & 0 & 1.5 \\
\hline MCPA application & (kg/ha) & 6.7 & 9.9 & 6.7 & 9.9 \\
\hline MCPA load & (g/ha) & 23.1 & 35.6 & 23.1 & 35.6 \\
\hline Glyphosate load & (g/ha) & 0.0 & 4.2 & 0.0 & 4.2 \\
\hline Nitrogen application & (kg/ha) & 97.0 & 138.0 & 97.0 & 138.0 \\
\hline Phosphorus application & (kg/ha) & 14.6 & 20.7 & 14.6 & 20.7 \\
\hline Nitrogen load & (kg/ha) & 14.7 & 10.5 & 20.8 & 27.6 \\
\hline Particulate phosphorus load & (kg/ha) & 2.82 & 0.86 & 0.10 & 0.07 \\
\hline Dissolved reactive phosphorus load & (kg/ha) & 0.31 & 1.07 & 0.65 & 0.70 \\
\hline Damage from herbicide load & (EUR/ha) & 4 & 8 & 4 & 8 \\
\hline Damage from nutrient load & (EUR/ha) & 1,303 & 854 & 916 & 1,160 \\
\hline Total damage & (EUR/ha) & 1,307 & 862 & 920 & 1,168 \\
\hline $\begin{array}{l}\text { Lower bound, 95\% confidence } \\
\text { interval }\end{array}$ & (EUR/ha) & 1,278 & 732 & 879 & 853 \\
\hline $\begin{array}{l}\text { Upper bound, 95\% confidence } \\
\text { interval }\end{array}$ & (EUR/ha) & 1,338 & 1,051 & 966 & 1,627 \\
\hline
\end{tabular}

Table 9. Environmental damage computed from average observed input uses

\begin{tabular}{rccc}
\hline & $\begin{array}{c}\text { Damage from } \\
\text { herbicide } \\
\text { loading } \\
\text { (EUR/ha) }\end{array}$ & $\begin{array}{c}\text { Damage from } \\
\text { nutrient loading } \\
\text { (EUR/ha) }\end{array}$ & $\begin{array}{c}\text { Total damage } \\
\text { (EUR/ha) }\end{array}$ \\
\hline $\begin{array}{r}\text { Parameters from Lankoski et al. } \\
\text { Conventional tillage }\end{array}$ & 5 & & \\
No-till & 4 & 1,281 & $\mathbf{1 , 2 8 6}$ \\
Parameters from Helin et al. & & 695 & $\mathbf{6 9 9}$ \\
Conventional tillage & 5 & & $\mathbf{8 9 0}$ \\
No-till & 4 & 764 & $\mathbf{7 6 8}$ \\
\hline
\end{tabular}




\section{Endnotes}

${ }^{\mathrm{i}}$ No-till was found to provide higher social and private profit than conventional tillage for barley, but not for wheat and oats.

ii There are currently about 95 million hectares under no-till in the world, of which 23\% are in the US and Canada, 47\% in Argentina and Brazil, and 9\% in Australia. In Argentina and Brazil, $60 \%$ of the total arable land is under no-till. In the US, no-till practices are used on 23\% of the total arable land (source: European Conservation Agriculture Federation, http://www.ecaf.org/).

${ }^{\text {iii }}$ Using data on the same farmers over the years 1998-2003, Koundouri et al. (2009) found evidence that the farmers were risk-averse before Finland's accession in the European Union in 1995 and risk-lovers after, due to the increase in the non-random part of farm income brought along by the application of the Common Agricultural Policy. For the period under consideration in this article, 1998-2003, Koundouri et al. estimated the risk premium to be between -1 and -2 of farmer's profit. Given the low risk premium, we think that assuming farmers risk-neutrality over the 1998-2003 period is a reasonable approximation.

iv The sample is a rotating panel random sample. The rotating speed is on average $5-10 \%$ per year but changes yearly.

${ }^{\mathrm{v}}$ Unfortunately, the data do not include fuel expenditure.

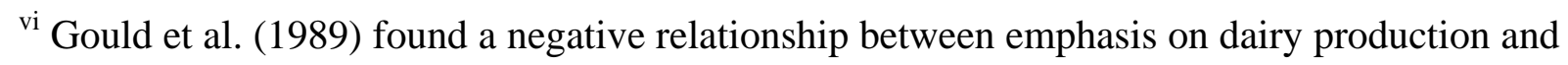
adoption of conservation tillage.

${ }^{\text {vii }}$ It is difficult to check if our sample is representative since the official agricultural statistics only contain information on the grain area under no-till, not on the number of farmers using a no-till machine. In 2005, the no-till area was around 9 percent (source: The Information Centre of the Ministry of Agriculture and Forestry). The difference between this number and the percentage of farmers in our sample owning a no-till machine probably reflects the fact that farmers may also choose to use contractors for no-till. Owning the machine is a proxy for adoption that may underestimate the actual rate of adoption.

viii The first and second derivatives of the log-likelihood function are weighted likewise and the asymptotic covariance matrix is corrected (Greene 2003).

${ }^{\text {ix }}$ Sample mean here refers to the farm with the average characteristics.

${ }^{\mathrm{x}}$ The relative nutrient losses produced by the different crops were held fixed. For nitrogen, the relative loads for the different crops were based on field experiments in South-Western 
Finland. For phosphorus, the relative loads were based on simulations from the IceCream model (Tattari et al. 2001). Land allocation and nutrient loads were set equal to the levels observed in 2003.

xi The confidence intervals for the damages under conventional tillage and no-till ([1,278 EUR/ha;1,338 EUR/ha] and [732 EUR/ha;1,051 EUR/ha]) do not overlap.

xii The two confidence intervals overlap, but the values of the lower and upper bounds indicate that in most cases the damage under no-till is likely to be greater than the damage under conventional tillage.

xiii While a production function associated with the Translog cost function does exist, is not mathematically tractable (see e.g. Beattie and Taylor, 1985). Thus, we are not able to derive a production function dual from our cost function estimates. 


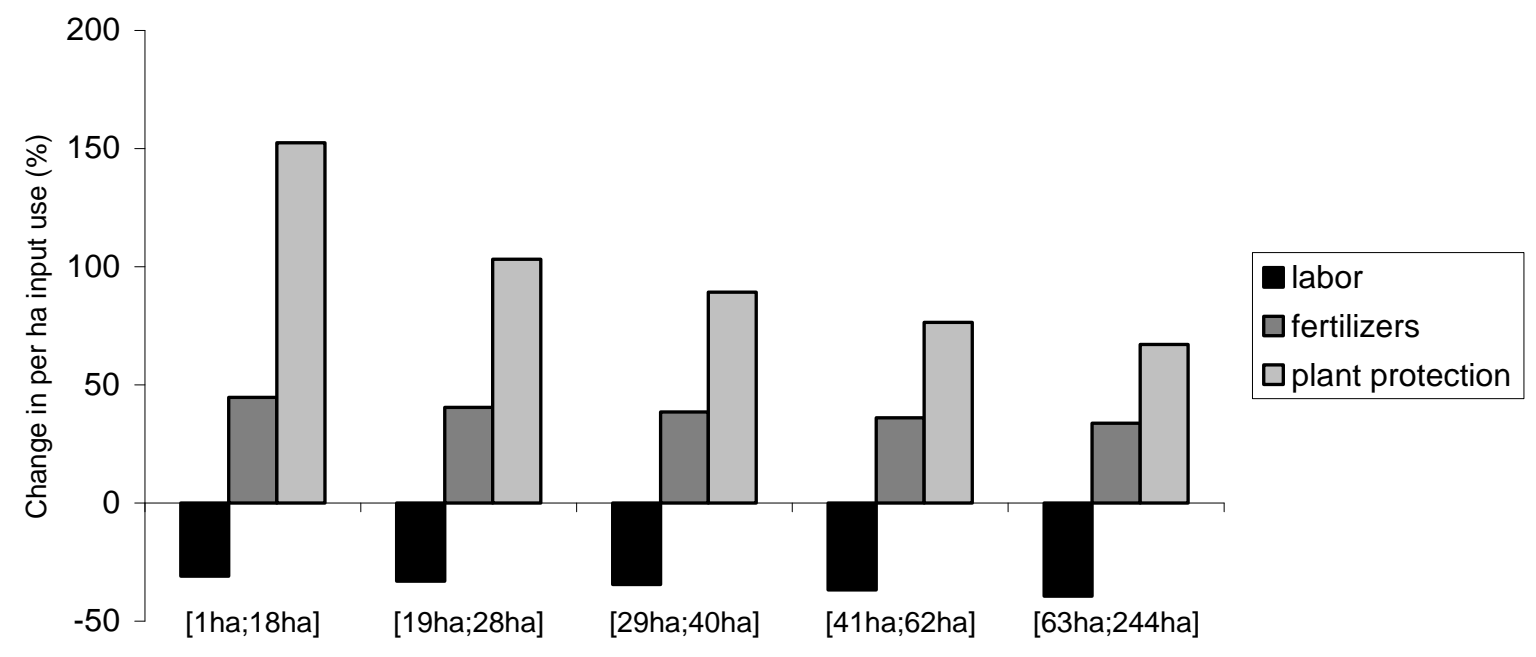

Figure 1. Percentage change in per hectare input use for farms of different sizes. 